\title{
Inventory "By Computer"
}

\begin{abstract}
A by-product of computerization of the circulation system at the State University of New York at Stony Brook was an inventory of the library collection. With the shelflist as a source, punched cards were produced for each of the volumes in the collection. After the cards were inserted in volumes in the collection, approximately one-tenth remained without matching books. Investigation uncovered that, of this total, 27 percent proved to be keypunching errors, 1 percent were labeling or typing errors, 11 percent were books that were subsequently located, and 61 percent (representing 6 percent of the total collection) were judged to be lost. Steps were then undertaken to replace these missing volumes or to withdraw their records from the catalogs.
\end{abstract}

W

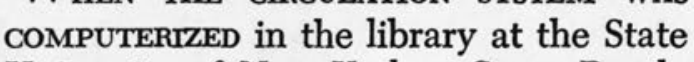
University of New York at Stony Brook, there occurred many obvious benefits. Users found it easier and less time-consuming to charge out a book. Circulation staff had less filing. Print-outs of books in circulation could be, and were, produced and made available at such key points as the public catalog and so saved readers fruitless trips to the stack.

One incidental by-product that also proved of value was the use of this new circulation system to make possible a new type of inventory.

Library literature on inventories is not plentiful. What does exist mentions five basic types: Counting the collection; taking the shelflist drawers to the shelf; taking the books to the shelflist; photocopying the shelflist; and writing worksheets for each title. The use of punched cards for this purpose has not, to the author's knowledge, so far been reported.

Catherine V. von Schon is Engish bibliographer in the library, State University of New York at Stony Brook.

\section{Sampling and Volume Counts}

Much of the literature describes methods for counting or estimating the percentage of loss, but not identifying all missing titles. For example, Robert N. Sheridan reported in 1974 on a twoyear study made at the Levittown Public Library. A volume count revealed a loss ranging from 11.5 to 17.1 percent in different categories of the collection. A second count six months to a year later was employed to establish a current loss rate. ${ }^{1}$

Similar collection counts have been made by other libraries, sometimes preliminary to a full-scale inventory. It is apparent that such a procedure does establish the percentage and perhaps the rate of loss, but it does not identify the missing books or help the staff to replace them or to correct the records.

Another procedure used to determine if an inventory is desirable is a sample inventory. At Ohio State University, for example, such a project was undertaken in 1967. A 1 percent sample $(5,742)$ of cards was selected from the shelflist, and shelves were checked. A loss rate of 4.37 percent was established, and the li- 
brary decided that a full inventory was not justified. ${ }^{2}$

In recent years estimates of loss rate have often been sought in order to determine whether or not to acquire an electronic security system. Two recent reports, of projects conducted at the University of Pennsylvania and Washington University, St. Louis, recorded sample inventories and searches made for missing volumes., 4

\section{Full INVENTORIES}

At IBM's Thomas J. Watson Research Center Library, a small special library with a collection of 34,952 titles, a procedure was followed of having a page bring the books to a two-person team who checked the shelflist. ${ }^{5}$ Such a laborious procedure would be out of the question in a large university library.

At Johns Hopkins, a university library approaching two million volumes, an inventory was begun in 1967, and it was expected to take ten years. At the time of a 1969 report it was stated that 200,000 volumes had been checked. ${ }^{6}$ The procedure was to copy call numbers from shelflist cards onto worksheets. Thus no cards were removed from the shelflist. Clerks took the worksheets to the shelf to locate the matching books. Such a procedure does, of course, represent the ultimate in security for the shelflist, but it also involves much waste motion in the preparation of worksheets for all titles, including those which are not missing.

Apparently less time-consuming than some of the above-mentioned methods is a procedure advocated in a study made by Beck and McKinnon for the University of Michigan and also followed by the Houston Public Library.7, 8 In this procedure the shelflist drawer is taken to the shelf by a two-person team. One person reads call numbers from cards while the other checks the shelf. An inventory control card is then completed only for "missing" items.

\section{STONY Brook CoMPUTERIZES}

At Stony Brook spot inventories had led the library to assume a loss rate of about 10 to 12 percent after the library had been in existence about thirteen years. The main impetus for the inventory, however, came from the computerization of the circulation records.

For this purpose, a corps of student keypunch operators was hired and instructed to produce a punched card for each monographic volume and copy recorded in the shelflist and serial records. Non-circulating materials (such as periodicals, reference books, items in special collections, documents, and microforms) were not included. Nor did the branch libraries, which continued to use their manual circulation systems, participate.

When the keypunching was completed and about 320,000 punched cards had been prepared, the entire library staff joined in a major project between semesters to insert book pockets and punched cards in books in the main stack collection.

In most cases, the staff member found a book with a call number exactly matching that on the card, pasted in a book pocket, and inserted the punched card, which was thereafter used in circulating the book. If no book was located to match a given punched card, the staff member went on to the next card, ending the assigned stint with a batch of unmatched cards. If there was no card for a book on the shelf, the staff member removed the book from the shelf, and a special unit took such unmatched volumes and prepared punched cards for them.

At the end of the project, the circulation department matched the remaining cards with the existing manual circulation records and, where appropriate, attached the punched card to the circulation slip, to be inserted in the book when returned. The circulation depart- 
ment also checked the stack a second time to locate books to match the remaining cards.

At the end of this second search, approximately 30,000 punched cards were left for which matching books could not be found, about 10 percent of the total.

Up to this point computerization of the circulation operation had been the only objective. Now, however, the library administration became concerned about the 30,000 apparently missing books and decided to take action to investigate and, if necessary, replace them. This finding also prompted the administration to discuss and look into electronic door check systems, resulting in the installation about two years later of such a system.

\section{The Replacement Project}

A new position, replacement searcher, at the level of a technical assistant (para-professional), was created to devote full time to the problem of these 30,000 orphan punched cards, and the author was asked to devise procedures for the project and to train the staff member. In March 1973 the project got underway. Records for the punched cards were purged from the computer's memory, and if books were later found, new punched cards were made.

The new staff member began the project by re-matching the cards with the shelflist. In this operation she removed the shelflist card from the catalog, replacing it temporarily with the punched card. In the process, a number of errors on the part of the original keypunch operators were discovered, averaging about 27 percent of this residue.

A keypunch error was recorded wherever the card did not match a shelflist card exactly; and the punched card was discarded. A frequent source of error was failure to notice that a title was a multi-volume set and consequent production of a card without volume indi- cation. Other errors included omission of date from the call number and misreading of call numbers.

In 73 percent of the cases the replacement searcher did find matching shelflist cards, and she wrote "lost" and added the date and her initials in pencil.

The stack collection was now searched a third time. To our surprise a small but significant group (about 13 percent) of the supposedly missing books were found. Since these punched cards had already been purged from the computer memory, they were discarded at this point and the number of books located recorded on a statistics sheet as "found." The new computer circulation file was also consulted; and the occasional books found to be charged out were included in the "found" statistics. The searcher took no action at this time about obtaining new punched cards for these books as new cards were generated automatically for any uncarded books whenever they were presented for borrowing at the circulation desk.

Presumable explanations for finding books on the third search include "unofficial borrowing" and subsequent return of a book as well as possible misshelvings at the times of earlier searches.

For each book found at this time the searcher erased the "lost" notation from the shelflist card, discarded the punched card, and filed the shelflist card.

Remaining shelflist cards were photocopied and then refiled, and all remaining punched cards were discarded. The "lost" notations remained on these cards in the shelflist as information to library staff consulting the shelflist.

One may object that there is lack of security in removing shelflist cards and carrying batches of them around the building; but in refiling they are matched with the punched cards, and this served as a check against possible 
loss. Throughout the project no shelflist cards were lost.

One serendipitous by-product of the project was the discovery of a small percentage of cataloging, typing, labeling, and other minor errors. These included books which did not match the shelflist card exactly but were close enough to cause the searcher to investigate. Most were cases in which either the labeler or the typist had made an error as the book or card was processed. Many involved omitted dates or volume numbers. Some were cases of misreading; PG and PQ were often confused, as were $\mathrm{U}$ and $\mathrm{V}$ in the Cutter number. Such errors were, of course, corrected, and the items were subtracted from our total of missing books. We are aware that there may be other such errors still not discovered in the stack.

While refiling the shelflist cards for the titles actually determined to be missing, the replacement searcher noted on the corresponding photocopy any relevant information, such as "have 2 copies of 1968 edition," which might be helpful to the person making a replacement decision. She took the photocopies to the appropriate subject specialist on the library staff or on the teaching faculty, who then made a decision to "buy now," "buy later," or "withdraw" for each item. Budgetary restraints were taken into consideration in making these decisions, as well as a number of other elements, for example, present and future course offerings at the university, strengths and weaknesses of the collection in the subject, or the importance of the particular book or author.

When the photocopy slips were returned to the replacement searcher with the specialist's decisions, she removed card sets from the public catalog for the "withdraw" and "buy later" items, thus ending the frustration of users who are led to believe a book is in the stack when it is actually lost. The card sets for withdrawn titles were filed in a special "withdrawn" file in the catalog department, for potential re-use at a future date. The notation, "lost," on the shelflist card was changed to read "withdrawn." Card sets for "buy later" books were placed in a special file beside the desk of the replacement searcher, to be sent to the acquisitions department with an order at a later date when and if funds became available.

For the "buy now" items, the replacement searcher consulted appropriate sources and placed orders for those items in print, using a special abbreviated form of the usual order procedure. The acquisitions department agreed to accept the photocopy of the shelflist card as supplying all necessary bibliographic information. The replacement searcher stapled this to an order slip, on which she had to write only the price, the name of the requesting specialist, and the fund (a special "replacement" fund had been designated in the budget). In cases where the same edition was not available, the searcher crossed out the imprint on the photocopy and wrote in the new imprint. Those items which were out of print were channeled into the o.p. search routine.

\section{Findings}

This project, as mentioned above, began in March 1973. It was completed in September 1976. In fiscal 1973/74 (April 1973 through March 1974) 11,823 punched cards were processed. In fiscal $1974 / 75,10,608$ cards were handled, and in the period from April 1975 to September 1976, 9,343 items. Table 1 summarizes the project in terms of cards handled and the disposition for the major categories. The missing 19,253 volumes, indicated in Table 1, represented approximately 6 percent of the total 320,000 cards with which the project began.

The number of volumes missing was, of course, greater than the number of titles missing in whole or in part, since 
TABLE 1

Cards Processed in Inventory, 1973-1976

\begin{tabular}{lrr}
\hline \hline & Number & Percent \\
\hline Keypunch errors & 8,644 & 27 \\
Books found & 3,576 & 11 \\
Cataloging errors & 301 & 1 \\
Net volumes missing & 19,253 & $\underline{61}$ \\
Total cards processed & 31,774 & $\mathbf{1 0 0}$ \\
\hline
\end{tabular}

in many cases two or more copies of the same title, or two or more volumes of the same title, were missing. Titles missing in whole or in part were 16,467 , as opposed to 19,253 volumes missing. The decisions made by various subject specialists on these 16,467 titles are shown in Table 2. Of the 8,306 titles designated for immediate purchase, the searcher found that 5,909 (71 percent) were in print and 2,397 (29 percent) were out of print.

TABLE 2

Decisions Made on Missing Trtues

\begin{tabular}{lrc}
\hline \hline & Number & Percent \\
\hline Withdraw & 6,781 & 41 \\
Set aside to buy later & 1,380 & 8.5 \\
Buy now & 8,306 & 50.5 \\
Titles missing & 16,467 & 100 \\
\hline
\end{tabular}

During its first twenty-one months, the project occupied one technical assistant full-time. In addition, two subject specialist librarians, those responsible for English and psychology, devoted substantial time to searching their own sections of the collection. A graduate student from the history department worked half-time for one academic year and processed all books in the $\mathrm{E}$ and $\mathrm{F}$ classes. The philosophy department also supplied student help, and a clerk was available for part of the time. In 1975 the technical assistant was reassigned elsewhere, and the project continued more slowly with a half-time clerk. In 1976 the technical assistant was reassigned to finish the project, and during spring vacation she received considerable volunteer help to withdraw card sets from the public catalog. The project was completed in September 1976three years and six months after it started.

\section{Cost}

It is difficult to estimate the cost of the project as so much may depend on the pay scale of the staff involved, and in this project all types of employees participated at one time or another.

A comparison for one part of the operation with another method, however, in terms of time can be made. A test was undertaken, doing one shelflist drawer by the Stony Brook method and one by the method used in Houston (in which the shelflist drawer was taken to the stack and cards compared with books one by one).

The "Stony Brook" test drawer contained eight inches of cards and required twenty minutes or two and onehalf minutes per inch of cards. The "Houston" test drawer had six and onehalf inches of cards, and seventy minutes were required, or over ten minutes per inch. Even if one ignores the customary practice of using two staff members for the conventional inventory, four times as much staff time is required as with this new method. Including the factor of double staff, we might conclude that the "Houston" method involves eight times as much staff time.

Convenience and economy of operation may, therefore, be stated as the prime arguments in favor of the Stony Brook method. Admittedly, it has its drawbacks. As with most library inventories, when an inventory extends over a long period of time-as it did at Stony Brook-individual books can escape the net through mis-shelving and other accidents. The Stony Brook method is, of course, applicable only in certain libraries, and then only at one specific time: when the library is converting its records into a machine-read- 
able format. But for libraries meeting these rather specific qualifications, we may recommend it as a useful and timesaving tool.

\section{REFERENCES}

1. Robert N. Sheridan, "Measuring Book Disappearance," Library Journal 99:2040-43 (Sept. 1, 1974).

2. Irene A. Braden, "Pilot Inventory of Library Holdings," ALA Bulletin 62:1129-31 (Oct. 1968).

3. Michael Bommer and Bernard Ford, "A Cost-Benefit Analysis for Determining the Value of an Electronic Security System," College \& Research Libraries 35:270-79 (July 1974).
4. Powell Niland and William H. Kurth, "Estimating Lost Volumes in a University Library Collection," College \& Research Libraries 37:128-36 (March 1976).

5. G. E. Randall, "The Inventory of a Special Library Collection," Special Libraries 63: 130-34 (March 1972).

6. Pamela Bluh, "A Study of an Inventory," Library Resources \& Technical Services 13: 367-71 (Summer 1969).

7. R. E. Beck and J. R. McKinnon, "Development of Methods and Time Standards for a Large-Scale Library Inventory," in Barton R. Burkhalter, ed., Case Studies in Systems Analysis in a University Library (Metuchen, N.J.: Scarecrow, 1968), p.48-75.

8. Jay B. Clark, "An Approach to Collection Inventory," College \& Research Libraries 35:350-53 (Sept. 1974). 